\title{
Exile and Return from the Far North of Scotland from the Reformation to the Revolution
}

Exil et retour : le cas du Nord de l'Écosse, de la réformation à la révolution

\section{Thomas Brochard}

\section{(2) OpenEdition \\ 1 Journals}

\section{Electronic version}

URL: https://journals.openedition.org/etudesecossaises/215

DOI: $10.4000 /$ etudesecossaises. 215

ISSN: 1969-6337

\section{Publisher}

UGA Éditions/Université Grenoble Alpes

\section{Printed version}

Date of publication: 30 September 2010

Number of pages: 19-39

ISBN: 978-2-84310-173-1

ISSN: $1240-1439$

\section{Electronic reference}

Thomas Brochard, "Exile and Return from the Far North of Scotland from the Reformation to the Revolution", Études écossaises [Online], 13 | 2010, Online since 30 September 2011, connection on 11 April 2023. URL: http://journals.openedition.org/etudesecossaises/215 ; DOl: https://doi.org/10.4000/ etudesecossaises.215 


\section{Exile and Return from the Far North of Scotland from the Reformation to the Revolution}

The exile and return of individuals from the far north of Scotland from 1560 to 1640 can be viewed within the perspective of a "civilizing process" and its dual core of social discipline from above and social regulation from below. This framework sets the movement of exiles within the larger context of the relationships between the Scottish/British Crown and the clan communities of Caithness, Sutherland, Ross, and the Outer Isles. Indeed, the Government promoted "exile" as a way to canalize clan militarism. It intended to relocate the potential offered by private armies into the public sphere-i.e., as an official, governmental institutionand regulate it. The rationale behind this exile policy points towards its own "civilizing" agenda, namely the reform of these boreal communities and the removal of the most rebellious minorities. Another parallel phenomenon was at work in the exile and return of primarily, but not solely, members of the clan elite not only to other Scottish towns outside their native environment but also to Europe for educational motives. In this respect, the process of fosterage conveyed a significant cultural and educational function that complemented institutional formation. Moreover, the clan elite participated in the broader cultural experience of the British nobility with continental travels. The return after this intellectual and behavioural enrichment or trauma had an impact both at the personal and community level, as these individuals wielded substantial powers locally in judicial and administrative terms. The transformation and "civilizing" of the Scottish outlying shires over the period resulted to some degree from the manifold experiences of their people. Exile and return was an integral part of the process of integration. The mechanics behind it need to be studied so as to expose teachings for a civilizational model entailed by such a process. Like Penelope, let us unravel the rich web of the far-northern culture. 


\section{Exile and return: canalizing militarism}

The concept of exile is ambiguous in the sense that its Latin root covers a broad spectrum of meanings. Unlike the "exulum trias" of Roman Cicero, Ovid, and Seneca, this paper has adopted one of the traditional etymological definitions of the Latin term exilium, essentially a change of place, a geographical movement "outside the land" (extra solum). In essence, this encapsulated a move away from one's community, a separation from one's patria, the land of the pater indeed. ${ }^{1}$ Traditional historiography has perceived the early-modern far north of Scotland - and the Highlands in general - and its people as a region that lacked dynamism to a degree and appeared sclerotic. The capacity for the exile of its people would thus seemingly be either low or high depending on whether one regarded inherent and exogenous factors as an obstacle or as an incentive to migration. In the conception of the Scottish far northern homo peregrinator over the period 1560 to 1640, two rich veins can be exploited to gauge such activity within these communities. The canalization of these people's militarism and their educational experiences in exile will be studied from the perspective of their integration within the greater Scottish/British polity and the so-called "civilizing" process of their perceived "barbarity". ${ }^{2}$

The military involvement of the clans at the local level in the Scottish far north provided the Crown with plentiful resources to be exploited in its "civilizing" process by its transposition to a structured national and

1. J. F. Gaertner, "The Discourse of Displacement in Greco-Roman Antiquity", in J. F. Gaertner (ed.), Writing Exile: The Discourse of Displacement in Greco-Roman Antiquity and Beyond (Leiden, 2007), pp. 1-20; G. H. Tucker, Homo Viator: Itineraries of Exile, Displacement and Writing in Renaissance Europe (Geneve, 2003), pp. 37-51, underlines the inner, psychological elements that distinguish exile from travel.

2. This apparent absence of relative dynamism is found in I. F. Grant and H. Cheape, Periods in Highland History (1987, rptd. London, 1997), pp. 105-36; J. Goodare, State and Society in Early Modern Scotland (Oxford, 1999). Indeed, the two major works on the Highlands and Islands for the period are essentially political narratives of clan conflicts and the Crown's efforts to pacify these lands: D. Gregory, The History of the Western Highlands and Isles of Scotland, from $\mathrm{AD} 1493$ to AD 1625 (2nd ed., London, 1881); W. C. Mackenzie, History of the Outer Hebrides (Paisley, 1903). On the broader issue of "civilizing" and the State, one can turn to A. MacCoinnich, "His Spirit Was Given Only to Warre': Conflict and Identity in the Scottish Gàidhealtachd c. 1580-c. 1630", in S. Murdoch and A. Mackillop (eds), Fighting for Identity: Scottish Military Experience, c. 1550-1900 (Leiden, 2002), pp. 133-61; A. Cathcart, "Crisis of Identity? Clan Chattan's Response to Government Policy in the Scottish Highlands, c. 1580-1609", in ibid., pp. 163-84; M. Greengrass, "Introduction: Conquest and Coalescence", in M. Greengrass (ed.), Conquest and Coalescence: The Shaping of the State in Early Modern Europe (London, 1991), pp. 1-24; J. H. Elliot, "A Europe of Composite Monarchies", Past and Present, vol. CXXXVII (1992), pp. 48-71; B. Dmytryshyn, "The Administrative Apparatus of the Russian Colony in Siberia and Northern Asia, 1581-1700", in A. Wood (ed.), The History of Siberia: From Russian Conquest to Revolution (London, 1991), pp. 17-36. 
international setting. The central Government used and recycled the evident martial streak found in these local communities of the far north for service at home and abroad, whether it be on the restless Borders in 1581 or to support the Elizabethan campaign in the Nine Years' War (1594-1603) with the Iberian menace still potent. The Habsburg authorities replicated that move with the employment of the Senj uskoks in the Venetian and Austrian services. ${ }^{3}$ With this ad hoc policy, the executive strove to contain and regulate the clans' "barbarity" and warlike behaviour to serve its own ends at a national and especially international level.

The Thirty Years' War constituted the main vector for this military exile on an international scale. ${ }^{4}$ Military service in France offered comparable outlets throughout the period. ${ }^{5}$ Highlanders thus fully participated in a military capacity in the expansion of British imperial operations under King Charles I. Additionally, selective operations equally drew recruits from the area. In 1612, George Sinclair, illegitimate nephew of the earl of Caithness, conducted an expedition to Norway during the Kalmar War with 100 to 150 men from Caithness. ${ }^{6}$ The $1627-28$

3. The Register of the Privy Council of Scotland [RPC], J. H. Burton et al. (eds), 38 vols (Edinburgh, 1877-1970), 1st ser., vol. I, pp. 136-7; vol. III, pp. 355-6; Accounts of the Lord High Treasurer of Scotland [TA], ed. T. Dickson et al., 13 vols (Edinburgh, 1877-1978), vol. X, p. 147; Collectanea de Rebus Albanicis: Consisting of Original Papers and Documents Relating to the History of the Highlands and Islands of Scotland, ed. W. F. Skene (Iona Club, 1847), pp. 45-6. A fascinating insight can be found with the Senj uskoks: C. W. Bracewell, The Uskoks of Senj: Piracy, Banditry, and Holy War in the Sixteenth-Century Adriatic (Ithaca, 1992).

4. R. G. Asch, The Thirty Years War: The Holy Roman Empire and Europe, 1618-1648 (Basingstoke, 1997). For Scotland, the collection of essays edited by Steve Murdoch presents a broad and wideranging view of the war: S. Murdoch (ed.), Scotland and the Thirty Years' War, 1618-1648 (Leiden, 2001); A. Grosjean, An Unofficial Alliance: Scotland and Sweden, 1569-1654 (Leiden, 2003), chs 2-3. The British imperial context is summarized in A. I. Macinnes, The British Revolution, 1629-1660 (Basingstoke, 2005), pp. 47-54.

5. For far northerners in connection with the French army and the Scots Guard in France and its wider context, see Edinburgh University Library [EUL], Laing Collection, La. III. 666, p. 59; National Archives of Scotland [NAS], Edinburgh, Gordon Castle Muniments, GD44/14/4/5; F. Michel, Les Écossais en France, Les Français en Écosse, 2 vols (London, 1862), vol. I, pp. 9, 487-8; vol. II, pp. 50, 233-6, 283-5, 526; M. Glozier, Scottish Soldiers in France in the Reign of the Sun King: Nursery for Men of Honour (Leiden, 2004), chs 1-2; M. Glozier, "Scots in the French and Dutch Armies during the Thirty Years' War", in Murdoch, Scotland and the Thirty Years' War, pp. 117-41; W. Gordon, The History of the Ancient, Noble, and Illustrious Family of Gordon, from Their First Arrival in Scotland, in Malcolm III's Time, to the Year 1690, 2 vols (Edinburgh, 1726-27), vol. II, pp. 611-3, 624-30; R. Monro, Monro His Expedition with the Worthy Scots Regiment (Called Mac-Keyes Regiment) (London, 1637), vol. I, p. 45.

6. The military campaign in Norway features in National Library of Scotland [NLS], Edinburgh, P. Henderson, "Notes of the History of Caithness", Acc. 9798, under the year 1613; R. Gordon, $A$ Genealogical History of the Earldom of Sutherland (Edinburgh, 1813), pp. 288-9; J. Calder, Sketch of the Civil and Traditional History of Caithness, From the Tenth Century (2nd ed., Wick, 1887), pp. 142-8, 301-2, 327; T. Michell, History of the Scottish Expedition to Norway in 1612 (London, 1886); T. A. Fischer, The Scots in Sweden: Being a Contribution towards the History of the Scot Abroad (Edinburgh, 1907), pp. 75-84, 224. Far northerners also served in Holland: Papers Illustrating the History of the Scots Brigade in the 
mission to the île de Ré and La Rochelle set sail with Sutherland and possibly Seaforth men, but no Clanranald men despite Clanranald's bond to the earl of Morton for 150 men as a captain in his regiment. ${ }^{7}$ The martial training of clansmen had to be adjusted in order to integrate them into a stricter military discipline and to reduce commotions and brawls within this military milieu. ${ }^{8}$

The Crown actively sought the concurrence of the local elite with its political and military decisions. Indeed, this move was doubly beneficial. It was essentially a way of eradicating the most troublesome elements of the region while securing cheap recruits for its foreign campaigns, as practiced in the respective contexts of Ireland and the Ottoman Empire. Towards that end, it repeatedly passed legislation to enlist social outcasts, certain categories of criminals, and prisoners to join military service, particularly as recruitment already proved to be difficult by April 1627. But, by means of the statute-book, the Crown regulated military recruitment to prevent procedural abuses, notably impressment. ${ }^{9}$

Service of the United Netherlands, 1572-1782, vol. I, ed. J. Ferguson (Scottish History Society, 1899), pp. 58-60, 62-3, 66, 69, 72, 74, 214-5, 226, 229 n. 5, 232, 291-2; A. Mackenzie, History of the Mackenzies with Genealogies of the Principal Families of the Name (2nd ed., 1894, Markham, Ont., 1998, rpt. 2002), p. 61.

7. The expedition to the île de Ré is treated in The Chronicle of Perth; A Register of Remarkable Occurrences, Chiefly Connected with That City, from the Year 1210 to 1668, ed. J. Maidment (Maitland Club, 1831), p. 31; J. Balfour, The Historical Works of Sir Fames Balfour, ed. J. Haig, 4 vols (Edinburgh, 1824-25), vol. II, pp. 158-9; Calendar of State Papers, Domestic Series, of the Reign of Charles I, 1625-49 [CSP, Dom.], J. Bruce et al. (eds), 23 vols (London, 1858-97), 1627-28, pp. 285, 453, 515; D. Gregory, "Notices Regarding Scotish Archery, Particularly That of the Highlanders; Together with Some Original Documents Relating to a Levy of Highland Bowmen to Serve in the War against France, in the Year 1627”, Archaeologia Scotica, vol. III (1831), pp. 252-4; NLS, Morton Papers, MS 82, nos. 32, 55; MS 84, no. 5; Gordons of Gordonstoun and Cummings of Altyre Papers, Dep. 175/65, nos. 162, 177; Dep. 175/88/1; Gordon, Earldom, 408; RPC, 2nd ser., vol. II, pp. 37-8, 55-6, 90, 118, 136, 285, 308, 577. In Aug. 1627, King Charles required Colin, 1st Earl of Seaforth, to contribute men to serve in France: The Earl of Stirling's Register of Royal Letters, Relative to the Affairs of Scotland and Nova Scotia from 1615 to 1635, ed. C. Rogers, 2 vols (Edinburgh, 1885), vol. I, pp. 195-6.

8. Extracts from the Council Register of the Burgh of Aberdeen, 1625-1642, ed. J. Stuart (Scottish Burgh Records Society, 1871), pp. 8-9; J. Mackay, An Old Scots Brigade: Being the History of Mackay's Regiment Now Incorporated with the Royal Scots (Edinburgh, 1885), pp. 219-22.

9. NAS, Justiciary Records, Books of Adjournal, JC2/6, fo. 191v; Earl of Stirling's Register, ed. Rogers, vol. I, p. 146; RPC, 1st ser., vol. XII, pp. 255, 431, 453; 2nd ser., vol. I, pp. 542-3, 546-7, 565-7, 580-1, 585, 589, 603-5, 608, 611-3, 635-6; vol. II, pp. 7-8, 32-7, 229, 332-3; vol. III, p. 197; vol. VI, pp. 28-9; Fischer, Scots in Sweden, p. 91; G. Henry, The Irish Military Community in Spanish Flanders, 1586-1621 (Blackrock, Co. Dublin, 1992), pp. 22-37; K. Barkey, Bandits and Bureaucrats: The Ottoman Route to State Centralization (Ithaca, 1994, rptd. 1997), ch. 6. In an echo to this policy of levying unsubjected Highlanders, in the second half of the 18th century, the Hanoverian Government would enrol the defeated Jacobite clansmen for service in the British army in the colonies: A. Mackillop, "More Fruitful Than the Soil": Army, Empire, and the Scottish Highlands, 1715-1815 (East Linton, 2000), ch. 2. 
On the other hand, motivations for choosing military service and exile from one's community were complex and varied according to the situation of each individual. Besides, even more so within a clan society, collective causes complemented personal ones. Sets of push-pull factors, both personal and independent of one's will, moulded an individual's decision whether to enlist or not, whenever press-ganging was not involved. Financial rewards in the form of pensions, wages, and bounties were not altogether irrelevant. ${ }^{10}$ Clanship and clan ties reinforced military participation, as did kinship overall for Scottish migration. People capitalized on these as networks to gain promotion or acquire position inter alia in the military sphere. Interestingly, William Gunn, the nephew of one of the arsonists at Sandside in 1615, served in the same company as John Innes, son of William whose corn was burnt in the process. ${ }^{11}$ Additionally, direct and indirect correspondence between the continent and these boreal townships influenced military engagement through its encouraging or dissuading words. ${ }^{12}$

10. NLS, Culloden Papers, MS 2961, fos 27r-8v; NAS, Hamilton Muniments, GD406/1/9320; Scottish Catholic Archives [SCA], Edinburgh, Colleges Abroad, CA4/9/6; S. Murdoch, "Introduction", in Murdoch, Scotland and the Thirty Years' War, pp. 15-8; Henry, Irish Military Community, pp. 48-52. Religious allegiance was a variable factor as opposed to being clearly polarized along denominational divides: Gordon under Arms: A Biographical Muster Roll of Officers Named Gordon in the Navies and Armies of Britain, Europe, America and in the Jacobite Risings, C. O. Skelton and J. M. Bulloch (eds) (New Spalding Club, 1912), nos. 122, 1656, 1754; D. Worthington, Scots in Habsburg Service, 1618-1648 (Leiden, 2004), pp. 88-9, 108-9, 146-50, 177-8, 239, 249, 278, 294-5; J. M. Bulloch, The Gay Adventures of Sir Alexander Gordon Knight of Navidale (Dingwall, 1925), pp. 13, 15, 19, 21-3; Fischer, Scots in Sweden, p. 266; M. R. Gunn, History of the Clan Gunn (Glasgow, 1969), pp. 126-9; S. Murdoch, "More Than Just 'Mackay's' and Mercenaries; Gaelic Influences in Scandinavia, 1580-1707", Transactions of the Gaelic Society of Inverness [TGSI], vol. LX (1997-98), pp. 167-8.

11. S. Murdoch, Network North: Scottish Kin, Commercial and Covert Associations in Northern Europe, 1603-1746 (Leiden, 2006), chs 1-3; Grosjean, Unofficial Alliance, chs 3, 5; D. Armitage, "Scottish Diaspora", in J. Wormald (ed.), Scotland: A History (Oxford, 2005), pp. 280-1; Gunn, Clan Gunn, pp. 126-9; The Munro Tree: A Genealogy and Chronology of the Munros of Foulis and Other Families of the Clan, A Manuscript Compiled in 1734, ed. R. W. Munro (Edinburgh, 1978), L/10, L/17, L/29, L/30, M/5, M/35, M/37, Q/14, Q/39-Q/40, R/4, R/5, R/21, T, U. Calendar of Documents Presented to H. M. General Register House, Edinburgh, by the Rt. Hon. the Baron Reay [Inventory of Reay Papers], ed. C. T. Innes (1929), 8/1; J. A. Fallon, "Scottish Mercenaries in the Service of Denmark and Sweden, 162632" (Ph.D. Thesis, University of Glasgow, 1972), pp. 288, 292-3. If Munro is not mistaken, then Captain Innes was indeed John and not Robert as confused by Mackay and Riis: Monro, His Expedition with the Worthy Scots Regiment Called Mac-Keys, ed. W. S. Brockington (Westport, Ct., 1999), p. 116; J. Mackay, An Old Scots Brigade: Being the History of Mackay's Regiment Now Incorporated with the Royal Scots (Edinburgh, 1885), p. 205; T. Riis, Should Auld Acquaintance Be Forgot.... Scottish-Danish Relations c. 1450-1707, 2 vols (Odense, 1988), vol. II, p. 130. On networks see NLS, Dep. 175/65, nos. 146-7, 162-3; Sutherland Papers, Dep. 313/489, no. 9; NAS, Reay Papers, GD84/2/170; GD406/1/458; The Sutherland Book, ed. W. Fraser, 3 vols (Edinburgh, 1892), vol. II, pp. 152, 161-2; Fallon, "Scottish Mercenaries", pp. 46-54.

12. NLS, Dep. 175/65, nos. 143ff, passim; Dep. 313/491, no. 1778; Social Life in Former Days: Second Series, Illustrated by Letters and Family Papers, ed. E. D. Dunbar (Edinburgh, 1866), pp. 28-30, 32-3, 57-64; Sutherland Book, ed. Fraser, II, pp. 38, 152-65. For the positive influence of war correspondence 
In order to assess the return of these soldiers and the effects of this homecoming on them and their society at large, it is necessary to understand the impact of the war on society at large. Death took an important toll on soldier numbers. Before even reaching the battlefields, the journey to and across the continent was itself a risky enterprise. ${ }^{13}$ Diseases similarly ravaged the ranks and reduced the regimental rolls usually by $10 \%$ at least. ${ }^{14}$ The war left a devastating trauma on individuals and to a lesser measure on the regional demographics in Scotland. It frustrated the potential for demographic growth through the depletion of the young male population. Conversely, demographic growth must also be related to the availability of land and of manufacturing processes. In the absence of either or both, a loss of population actually facilitated stability. Casualties among both the elite and ordinary clansmen distorted the social fabric of northern clanship, just as conscription did in the economically deprived area of Swedish Norrland. ${ }^{15}$

War inflicted psychological scars both on the exiles themselves and their home communities. For women and their expectation of returning soldiers, the poetry of war experience voiced the traumatic consequences they endured. ${ }^{16}$ Undoubtedly, for those who survived and returned to Scotland, the ordeal occasioned them deep emotional and psychological strains as well as physical injuries. An inkling of this appeared in an undated petition by Donald, Lord Reay, to King Christian IV of Denmark. ${ }^{17}$ Only this shared harrowing experience and heartfelt compassion towards his wounded fellow soldiers can explain Robert Munro's

in Scotland, see D. Horsbroch, 'Wish You Were Here? Scottish Reactions to 'Postcards' Home from the 'Germane Warres"', in Murdoch, Scotland and the Thirty Years' War, pp. 245-69.

13. NLS, Dep. 175/65, no. 146; Gordon, Earldom, p. 473; Monro, Expedition, I, p. 64; II, pp. 3-4, 13; The Celtic Magazine, vol. X (1885), p. 235.

14. Monro, Expedition, vol. I, pp. 27, 65, 86; vol. II, pp. 8, 10, 12, 18, 23, 40, 47-9, 53, 59; Fallon, "Scottish Mercenaries", pp. 339-42; Fischer, Scots in Sweden, pp. 90, 100-2.

15. NAS, John MacGregor Collection, GD50/224/6; Munro of Foulis Writs, GD93/201; Cuninghame of Caprington Muniments, GD149/265/2, fo. 90r; NLS, Brydges MS, Adv. MS 6.1.17, fos. 92r-4r; Historical Manuscripts Commission [HMC], Eleventh Report, Appendix, Part VI: The Manuscripts of the Duke of Hamilton, ed. W. Fraser (London, 1887), p. 74; T. A. Fischer, The Scots in Germany: Being a Contribution towards the History of the Scot Abroad (Edinburgh, 1902), pp. 77-8, 90-1, 283-5; D. Kirby, Northern Europe in the Early Modern Period: The Baltic World, 1492-1772 (London, 1992), pp. 138-9, 146-7. It is argued that in 18th century Scotland, net migration, which included temporary emigrants like soldiers and merchant mariners, had a much lesser impact on the population than that of fertility and mortality: R. E. Tyson, "Demographic Change", in T. M. Devine and J. R. Young (eds), Eighteenth Century Scotland: New Perspectives (East Linton, 1999), pp. 197-8.

16. One of these songs ran "Oh, woe unto these cruell wars That ever they began! For they have reft my native isle Of many a pretty man. First they took my brothers twain Then wiled my love frae me: Oh, woe unto these cruell wars In low Germanie!” (Fischer, Scots in Germany, pp. 73-4.)

17. I. Grimble, "The Royal Payment of Mackay's Regiment", Scottish Gaelic Studies [SGS], vol. IX (1961), pp. 28-30. 
resolution to erect a hospital in Scotland for injured ex-servicemen in the spring and summer of 1634. However, a lack of funding and the later development of the Civil Wars meant that his project ultimately collapsed. ${ }^{18}$

Nevertheless, some of these military men needed little persuasion to continue their armed service either on the continent or in the British Isles in this belligerent context. ${ }^{19}$ Others exploited their influential networks and military achievements to move into the diplomatic/political sphere, such as John Gunn of Golspie, for example, who rose to the rank of colonel and in 1638 assumed the governorship of Ohlau (Oława) in Silesia. ${ }^{20}$ Scottish auxiliaries received and acquired estates and lands on the continent and advanced to the nobility. Though not a first generation Scot, Lieutenant-Colonel John Urquhart received three leaseholds from Queen Christina of Sweden in May 1645 for his military duties and was ennobled in 1648. Urquhart's case was part of the wider civilianization of the Scottish military in Swedish-held territories. ${ }^{21}$ The official employment of far northerners in the army did not preclude their continued interest in their personal or clan interests. Au contraire, it somewhat supplemented and amplified them. Likewise, despite Muscovy's military

18. Documents Relating to the Province of Moray, ed. E. D. Dunbar (Edinburgh, 1895), pp. 113-4; Mackay, Old Scots Brigade, pp. 204-8; Clan Munro Association, Clan Munro Magazine, vol. V (1955), pp. 25-8; Monro, Expedition, vol. II, pp. 13, 20-1, 31-2, 54-5, 65-6, 70-2; RPC, 2nd ser., vol. V, pp. 333-6, 349, 352-6; SCA, CA4/9/6. It is worth pointing out that Munro initiated this project prior to the battle of Nördlingen. The colonel nonetheless lost most of his regiment. Munro certainly returned to Sweden and fought on until 1639 while the Swedish armies regrouped and strengthened: Grosjean, Unofficial Alliance, pp. 97-103, 172; W. S. Brockington, "Robert Monro: Professional Soldier, Military Historian and Scotsman", in Murdoch, Scotland and the Thirty Years' War, pp. 219-220; "Scotland, Scandinavia and Northern Europe, 1580-1707" [SSNE], S. Murdoch and A. Grosjean (eds), available online at <http://www.st-andrews.ac.uk/history/ssne/index.php>, accessed 19-20 February 2005, ID no. 94.

19. Gordon under Arms, Skelton and Bulloch (eds), nos. 122, 832, 1656, 1734; Munro Tree, ed. Munro, M/44, R/6, R/21; Mackay, Old Scots Brigade, p. 252.

20. Fischer, Scots in Germany, p. 316; W. Macfarlane (ed.), Genealogical Collections concerning Families in Scotland, ed. J. T. Clark, 2 vols (Scottish Historical Society [SHS], 1900), vol. I, p. 101. The ubiquitous William Gunn developed an ever wider network moving first into a limited local circle of influence to enjoy finally British and continental connections. Gunn, the son of an accessory to arson, ended his career as a major-general and baron of the Holy Roman Empire: Fischer, Scots in Germany, p. 112; Fischer, Scots in Sweden, pp. 118, 266; NLS, Gordons of Gordonstoun and Cummings of Altyre Papers, Acc. 10824/3, bundle no. 94, Dec. 1623; Dep. 175/65, nos. 107, 120, 146, 163, 300; Dep. 313/489, no. 28a; Dep. 313/491, no. 1770; NAS, GD406/1/857; HMC, Eleventh Report, App., pp. 101, 104; Monro, Expedition, vol. II, pp. 23-4; Fallon, "Scottish Mercenaries", pp. 63, 117, 120, 288, 290, 292-3, 344, 377, 382, 384; Worthington, Scots in Habsburg Service, pp. 239, 249, 278; D. G. Thompson, "In the Footsteps of Sir William Gunn", Gunn Herald (Mar. 1999), available online at <http://www.geocities.com/cgherald/Archive/SirWilliamGunn.html>, accessed 27 August 2009.

21. H. Tayler, History of the Family of Urquhart (Aberdeen, 1946), pp. 7, 21, 61, 92; Fischer, Scots in Sweden, pp. 117-8, 237-8, 260, 263-4; Munro Tree, ed. Munro, L/17, Q/15. This civilianization is researched in Grosjean, Unofficial Alliance, ch. 5; and see Murdoch, Network North, pp. 359, 361-4. 
employment of Siberian Cossacks on the frontier, they still maintained their raids and combined their peripheral benefits with their national official position. ${ }^{22}$ Indeed, the war was not all doom and gloom for soldiers. Happier moments punctuated its course in the form of marriage, for example. ${ }^{23}$

On the other hand, after his service, Hector Munro of Culcraggie sold the estate to his remote cousin, John Munro, burgess of Edinburgh. With the royal payments for his expensive military investments often failing to materialize fully, on time, or at all, Donald, Lord Reay, was still insolvent by 1637. He finally disposed of the lands of Strathnaver to John, Earl of Sutherland, in 1642. ${ }^{24}$ Yet, military promotions and positions alternatively conveyed social and symbolic prestige. Indeed, beyond these material provisions, returning soldiers won appraisals and recognition from within the community, as experienced by brothers from Barra probably in around 1630-31:

Gum bu sin na fir allail, 'S gum bu sin na fir fhurail, Fhuair an urram 's a b'fhiach e; 'S math ur gnothach 'sa Ghearmailt, Gur neo-chearbach ur gniomh ann.

"Those were the famous men, Those were the watchful men, Who got honour and deserved it; You were well fitted to be in Germany, Your deed there was efficient." 25

Through its manifold military arrangements, the Crown aspired to channel the potential offered by private armies into the public sphere for its own mission civilisatrice, namely the reform of the far northerners and the removal of the most troublesome minorities. It coerced them into partial submission by integrating them into the Scottish/British State rather than annihilating them outright. The experiences of returning soldiers were as multifarious as their reasons for joining the army had been.

22. C. Witzenrath, Cossacks and the Russian Empire, 1598-1725: Manipulation, Rebellion and Expansion into Siberia (London, 2007), pp. 24-6, 36-8, 61, 76, 127, 140-1, 148, 152.

23. Munro Tree, ed. Munro, M/24, Q/15; The Scots Overseas: Emigrants and Adventurers from Argyll and the Northern Highlands (Part One), ed. D. Dobson (St Andrews, 1993), pp. 22, 27; D. [S.] Thomson, An Introduction to Gaelic Poetry (2nd ed., Edinburgh, 1990), pp. 60-1.

24. CSP, Dom., 1628-29, p. 555; A. Mackenzie, History of the Munros of Fowlis (Inverness, 1898), p. 360; NAS, GD84/2/173, pp. 178, 192; GD84/2/246, p. 33b; GD406/1/9656-7; Inventory of Reay Papers, ed. Innes, 3/1B, 2B, 3B, 4B; 8/2, 6, 12; 9/1-3, 7, 12; 12/1B-8B; 28/1-10, 1B-2B, 3B/1-4; 125/4-7; Gordon, Earldom, p. 509; Grimble, "Royal Payment", pp. 23-38; I. Grimble, Chief of Mackay (London, 1965), ch. 6; Letters of Two Centuries Chiefly Connected with Inverness and the Highlands, from 1616 to 1815, ed. C. Fraser-Mackintosh (Inverness, 1890), pp. 24-5, 34-6.

25. Gaelic Folksongs from the Isle of Barra, J. L. Campbell et al. (eds), (London, 1950), pp. 28-9. Sir Donald Mackay was made Lord Baron Reay in June 1628 in token of his military actions: NAS, GD84/2/169, 171; Mackay of Bighouse Muniments, GD87/2/2; Registrum Magni Sigilli Regum Scotorum; The Register of the Great Seal of Scotland, AD 1306-1668 [RMS], J. M. Thomson et al. (eds), 11 vols (Edinburgh, 1882-1914), vol. VIII, no. 1211. 
The trauma of war left important psychological marks on society owing to its extensive influence especially in tightly-knit kinship communities of the early-modern Scottish far north. The readjustment to civilian life meant that, due to financial pressure, a large number of landholding military men had to part with all or a portion of their estates. Others were forced to carry on their martial career. However, others even managed to climb the social ladder through the social, political, and diplomatic preferment that their military service had earned them either in exile or in the patria after their return.

\section{Exile and return: a cultural (re)vision}

More peaceful opportunities also presented themselves notably, though not restrictively, to the clan elite. There was a recognition amongst the upper ranks that social promotion could be achieved in various ways away from unlicensed sword power. Education thus became a key aspect in the formation of the clan elite youth, as it was in other rural parts of Europe. ${ }^{26}$ The education of children encompassed a broad segment of society through the active participation of the clan at large to meet these instructional needs, even if informally. As a consequence, exile from the communities occasionally took place at a relatively young age. For the well-to-do and aspiring gentry, peregrination in Europe opened up the means to cultivate oneself not merely academically but also culturally, and this had significant repercussions in the locality after their return given the powerful position of this social stratum.

Traditional historiography discredits any society mired in ignorance both of the knowledge of God and educationally. This biased picture is found in the contemporary Scottish Borders, the Mezzogiorno, and in late-medieval Tuscany, and is derived from secular and religious perceptions of its backwardness. ${ }^{27} \mathrm{~A}$ revised approach to these societies reveals

26. G. Astoul, Les Chemins du Savoir en Quercy et Rouergue à l'Époque Moderne : Alphabétisation et Apprentissages Culturels (Toulouse, 1999), pp. 93-5; D. Allan, "What's in a Name?': Pedigree and Propaganda in Seventeenth-Century Scotland", in E. J. Cowan and R. J. Finlay (eds), Scottish History: The Power of the Past (Edinburgh, 2002), pp. 161-2. This line of reasoning actually combined the two trends in the mainstream English humanist thought of the time whose ideal was to shape a belligerent aristocracy into gentlemanly scholar-soldiers rather than farmers or merchants: D. Shuger, "Irishmen, Aristocrats, and Other White Barbarians", Renaissance Quarterly, vol. 1 (1997), p. 520.

27. D. Withrington, "Education in the 17 th Century Highlands", in L. Maclean (ed.), The Seventeenth Century in the Highlands (Inverness, 1986), pp. 60-9; M. M. Meikle, A British Frontier?: Lairds and Gentlemen in the Eastern Borders, 1540-1603 (East Linton, 2004), ch. 5; S. K. Cohn, "Highlands and Lowlands in Late Medieval Tuscany", in D. Broun and M. MacGregor (eds), Mìorun Mòr nan Gall, "The Great Ill-Will of the Lowlander"?: Lowland Perceptions of the Highlands, Medieval and Modern (Glasgow, 2009), pp. 111-2, 122; J. D. Selwyn, A Paradise Inhabited by Devils: The Fesuits' Civilizing 
new elements and findings. Some of these mountain peoples were in fact educated locally after having received their initial education within the family home, as was common among the Scottish nobility and in families of the French Hautes Alpes. ${ }^{28}$

In addition to an institutional instruction, and as observed elsewhere across early-modern Europe, people in these lands sought alternatives and invested in the upbringing of their children, recognizing their potential as human capital. ${ }^{29}$ The practice of fosterage was widely used throughout Scotland, Ireland, and western Eurasia and was important in the creation of networks of dynastic/clan or inter-familial allegiances and loyalties. Yet, its educational value is perhaps still somewhat under-valued. ${ }^{30}$ Fosterage consolidated the system of patronage for superiors while presenting a prudent investment towards social advancement for depend-

Mission in Early Modern Naples (Aldershot, 2004), introduction and ch. 1. The denigration of people
constitutive of the kingdom applied in the Swedish case against the Lapps: P. Burke, Popular Culture in
Early Modern Europe (1978, 3rd ed., Farnham, 2009), p. 152. MacGregor claims this irreligious strain
to be apparently a post-1560 construct as this did not feature in the late-medieval literati canon,
except for William Dunbar: M. MacGregor, "Gaelic Barbarity and Scottish Identity in the Later
Middle Ages", in Broun and MacGregor, Lowland Perceptions, p. 36 .
28. A.-M. Granet-Abisset, "Entre Autodidaxie et Scolarisation : Les Alpes Briançonnaises", His-
toire de l'Éducation, vol. LXXl (1996), p. 129. Gifts of chaplainries depicted a broad picture of local
education: NAS, Register of Privy Seal, PS1/61, fo. 10v; PS1/63, fo. 98v; Church of Scotland
Records, Miscellaneous Ecclesiastical Records, Register of Presentations to Benefices, CH4/1/1,
fos. 101v, 104v, 107v; CH4/1/2, fos. 21v, 4lr-v, 43v, 154r; Origines Parochiales Scotiae: The Antiqui-
ties Ecclesiastical and Territorial of the Parishes of Scotland [OPS], C. Innes and J. B. Brichan (eds),
2 vols (Bannatyne Club, 1851-55), vol. II, pp. 2, 422-5, 460, 586; Mackenzie, Munros, p. 302;
Old Ross-shire and Scotland As Seen in the Tain and Balnagown Documents, ed. W. Macgill, 2 vols (Inver-
ness, 1909-11), vol. I, no. 138; M. Dilworth, "Benedictine Monks of Ratisbon and Wurzburg in the
17th and 18th Centuries: émigrés from the Highlands of Scotland", TGSI, vol. XLIV (1964-66),
pp. 96 -7. The initial education of the nobility is discussed in K. M. Brown, Noble Society in Scotland:
Wealth, Family and Culture, from Reformation to Revolution (Edinburgh, 2004), pp. 181-2. 29. R. A. Houston, Literacy in Early Modern Europe: Culture and Education, 1500-1800 (2nd ed., Harlow, 2002), pp. 99-106, and pp. 106-23 for the motives and limitations in the search for the command of literacy; I. G. Tóth, Literacy and Written Culture in Early Modern Central Europe (Budapest, 2000), pp. 27-9; P. Bourdieu, "The Forms of Capital", in J. G. Richardson (ed.), Handbook of Theory and Research for the Sociology of Education (New York, 1986), pp. 243-6, 253; G. S. Becker, Human Capital: A Theoretical and Empirical Analysis, with Special Reference to Education (1964, 3rd ed., Chicago, 1993), pp. 15-26, 255-6.

30. This social geopolitical dimension of fosterage, namely the creation of alliances between and within kindreds, is discussed in A. Cathcart, Kinship and Clientage: Highland Clanship, 1451-1609 (Leiden, 2006), pp. 80-5; F. Fitzsimons, "Fosterage and Gossiprid in Late Medieval Ireland: Some New Evidence", in P. J. Duffy et al. (eds), Gaelic Ireland, c. 1250-c. 1650: Land, Lordship and Settlement (Dublin, 2001), pp. 138-49. The utilitarian capitalization of fosterage in relation to kinship as exercised by Scots abroad is most aptly analysed in Murdoch, Network North, ch. 1. On comparative adoptive kinship within a socio-political angle, one should consult P. Parkes, "Celtic Fosterage: Adoptive Kinship and Clientage in Northwest Europe", Comparative Studies in Society and History, vol. XLVIII (2006), pp. 359-95. 
ents. ${ }^{31}$ Oral culture must have to some extent infused the youth with means to gain cultural and educational development which are difficult to quantify given the nature of that process. Within that Platonic framework, fosterage should not be disregarded as a mere lever for the reinforcement and utilitarian promotion of kinship bonds and loyalties. As a system, it filled the social and cultural interstices of biological descent and marital alliances. ${ }^{32}$

Furthermore, albeit extensive as a custom, fosterage was not the universal apanage of mountainous communities which were also dedicated to the formation of youth within the home. ${ }^{33}$ It conveyed some educational and training values, if only minimally. ${ }^{34}$ The phenomenon was wide-spread not only geographically and socially but also in terms of gender. ${ }^{35}$ For example, prior to April 1602, Donald Thornton in the Chanonry of Ross entrusted his daughter Janet to Mr George Munro, Chancellor of Ross, for her education. ${ }^{36}$ Sometimes progeny was placed within a separate environment away from the community, as happened with Torquil Macleod, son of the laird (or possibly the breive) of Lewis, brought up by his mother's relatives in Strathconon. ${ }^{37}$

As in the Eastern Borders, testamentary evidence attested to these educational concerns on the part of the parents. ${ }^{38}$ The boarding of one's offspring with relatives, local/regional magnates, or even apparent strangers, by means of guardianship or otherwise, most certainly carried an

31. Parkes, "Celtic Fosterage", pp. 361-6; A. O. Curle, "Notice of Four Contracts or Bonds of Fosterage; with Notes on the Former Prevalence of the Custom of Fosterage in the Scottish Highlands", Proceedings of the Society of Antiquaries of Scotland [PSAS], vol. XXX (1895-96), pp. 12-4, 17, 19-21.

32. Murdoch, Network North, ch. 1; Cathcart, Kinship, pp. 80-5; Fitzsimons, "Fosterage and Gossiprid". For Plato, the art of reading and writing carried but the appearance of wisdom and only instruction led to true wisdom: Plato, Phaedrus, trans. H. N. Fowler (London, 1913), pp. 563, 565.

33. Granet-Abisset, "Entre Autodidaxie et Scolarisation", pp. 127-9 and 136-7, who contended that Alpine villages resorted to a mixture of home and school education, but also noted the possibility of a placement of the youth with a curate kin to learn Latin.

34. See the early Irish and Welsh practices and likewise that of the Ossetes in the North Caucasus in Parkes, "Celtic Fosterage", pp. 361-2, 362-3 n. 8, 374-5.

35. NAS, Commissariot of Edinburgh, Register of Testaments, CG8/8/31, p. 781; also CC8/ 8/29, p. 285; CC8/8/37, pp. 87, 329; NLS, Dep. 313/1597, year 1616, fo. 8v.

36. RPC, 1st ser., vol. VI, pp. 411-2; NAS, CC8/8/45, p. 183; Exchequer Records, Taxation Papers, E68/14/6, 5 May 1627; see also CC8/8/29, pp. 291-2. John Mackenzie of Gairloch had entrusted a daughter of his to Mr Robert Munro, most likely the treasurer of Ross, by 1607. Gairloch replicated the move with at least one of his sons cared for by Robert Leslie in the Chanonry. The location once again on the far north-eastern coast is significant: NAS, CC8/8/45, p. 669 .

37. I. F. Grant, The Macleods: The History of a Clan (1959), p. 127; The Book of Dunvegan, ed. R. C. MacLeod, vol. I (Third Spalding Club, 1938), pp. 120-1. Some Mackenzie instances of fostering can be found in Celtic Magazine, vol. II (1877), p. 110. On the strengthening of kinship bonds through fosterage, see M. Rackwitz, Travels to Terra Incognita: The Scottish Highlands and Hebrides in Early Modern Travellers'Accounts, c. 1600 to 1800 (Münster, 2007), pp. 242-7.

38. Meikle, British Frontier, pp. 165, 167. 
educational function whether formally at a local school or informally by way of nurture in the family. By September 1607, a young Hector Munro, the son of the Munro chief, Mr Hector, was entrusted to Mr George Munro, Chancellor of Ross. ${ }^{39}$ But, testamentary provisions towards the education of surviving children could only go as far as the goodwill of their tutors. ${ }^{40}$ Throughout these provisions for the cultivation of children in a foreign environment, real and fictive kinship played a pivotal role. ${ }^{41}$

In terms of higher education and with the absence of local universities, exile from their native soil was compulsory for far northerners, just as it was for Borderers. ${ }^{42}$ As had been the case from the Middle Ages, this required a knowledge in Latin, if not a conversance with it, to enable them to connect with the thinking and literature of the classical past and be in contact with the developing contemporary culture of Europe. ${ }^{43}$ Overall, there were probably well over a hundred students from the far north of Scotland who attended Scottish and European universities

39. NAS, CC8/8/45, p. 183; and also CC8/8/20, p. 407; CC8/8/24, p. 179; CC8/8/25, p. 273; CC8/8/35, pp. 61, 782; NLS, Acc. 10824/3, charge crop 1621 and sett 1622. Other instances of boarding in towns of the area's eastern seaboard and the Lowlands suggest at least the possibility of school education and perhaps apprenticeship for boys, including for Wester Ross families. Even a minor landlord like Angus Macculloch in/of Craighouse (Tarbat parish) was able to place his son Walter with Alexander Morrison, indweller in Leith, by 1599: NAS, CC8/8/35, p. 781; CC8/8/45, p. 669. Island families opted for Glasgow for instruction facilities and/or positions of apprenticeship: NAS, Glasgow Commissary Court Records, Register of Deeds, 1585-88, 1604-1700, CC9/14/4, fo. $164 \mathrm{r}$.

40. Thomas, the son of Sir John Sinclair of Greenland, was left in 1622 to "ye governement of ye laird of murkill [James Sinclair, Thomas' uncle] To be brocht up and trainit vp at scooles" (NAS, Caithness Commissary Court, Register of Deeds, CC4/8/1, fo. 4r). A generation before, in 1582, James Sinclair himself had been left with his cousin, Francis, Earl of Bothwell, to be governed, entertained, and sustained "at ye schuillis": SCA, Blairs Charters, BC14/4; also of interest is NAS, CC8/8/39, p. 321; Robertson of Kindeace Papers, GD146/10, testaments 1653-1793, Gilbert Robertson's testament.

41. In a number of instances, marital patterns are difficult to trace.

42. Meikle, British Frontier, pp. 168-72.

43. D. E. R. Watt, "Education in the Highlands in the Middle Ages", in L. Maclean (ed.), The Middle Ages in the Highlands (Inverness, 1981), pp. 80-9. On this Latinate culture in the far north, one should consult Report of the Committee of the Highland Society of Scotland, Appointed to Inquire into the Nature and Authenticity of the Poems of Ossian, ed. H. Mackenzie (Edinburgh, 1805), p. 50; J. Bannerman, "Literacy in the Highlands", in I. B. Cowan and D. Shaw (eds), The Renaissance and Reformation in Scotland (Edinburgh, 1983), pp. 214-35; R. Sharpe, "Roderick MacLean's Life of St Columba in Latin Verse (1549)", Innes Review [IR], vol. XLII (1991), pp. 111-32; Highland Papers, ed. J. R. N. Macphail, 4 vols (SHS, 1914-34), vol. I, pp. 8, 10-11; A. Cameron, Reliquiae Celticae, A. MacBain and J. Kennedy (eds), 2 vols (Inverness, 1892-94), vol. II, pp. 170-1; J. B. Craven, Descriptive Catalogue of the Bibliotheck of Kirkwall (1683), with a Notice of the Founder, William Baikie, M. A. of Holland (Kirkwall, 1897), pp. 20, 32; M. Anderson-Smith, "The Bibliotheck of Kirkwall", Northern Scotland, vol. XV (1995), pp. 128-30; Aberdeen University Library [AUL], Special Collections, volume shelf-marked "BK Rud [1-6]"; Book of Dunvegan, ed. MacLeod, vol. I, p. 184; NAS, GD146/10, inventory of old papers 1782 . 
over the period compared to the perhaps fifty to sixty students at European universities documented for the preceding two centuries, between c. 1200-1410. As one might expect, the vast majority of these students came from the nobility and landholding families, perhaps as much as $75 \%{ }^{44}$ Moreover, the sons of clergymen attended universities, possibly to the amount of $15-20 \%$, such as William Lauder at Aberdeen in the early 1630s, who was the son of James, minister at Avoch, or John Macrae, at both Aberdeen and St Andrews in the 1630s, whose father, Farquhar, officiated at the kirk of Kintail. ${ }^{45}$ In a marginal but revealing capacity, higher education opened up the possibility of social mobility for a number of families, be they tenants, town inhabitants, or clan officials. ${ }^{46}$ The relative absence of sons of burgesses in university records, as far as can be gathered, can be explained by their greater propensity to enter into indentured service with burgesses rather than going to university. It

44. Estimates of attendance are only tentative due to the partial survival of records, the proportion of attendants who never matriculated, the European-wide peregrinatio academica, and a high drop-out rate (Houston, Literacy, pp. 91-3). This number is the result of the perusal of a variety of sources too numerous to be listed, but primarily the Fasti Ecclesiae Scoticanae, ed. H. Scott, 8 vols (new ed., Edinburgh, 1915-50), vols VII-VIII, and the printed and manuscript registers of alumni and matriculations of the Universities of Aberdeen, Edinburgh, Glasgow, and St Andrews. There were about 64 students for whom their paternity was known and 48 of those were of noble or landholding stock. All the major families and clans of the far north had sons in higher education: Gordon, Gray, Macdonald, Mackenzie, Macleod, Macrae, Munro, Ross, and Sinclair, the last two perhaps underrepresented were it not for the fact that the name being found in these registers was a common one in Scotland. This is a major point as these registers mostly recorded first names and surnames with no other details, hence the difficulty in identifying Davidsons, Dunbars, Grays, Rosses, Sinclairs, Urquharts, and others. The medieval figures for the then dioceses of Caithness, Ross, Moray, and Argyll are taken from Watt, "Education in the Highlands", p. 87.

45. Fasti, ed. Scott, vol. VII, pp. 1, 33; Officers and Graduates of the University and King's College, Aberdeen, MVD-MDCCCLX, ed. P.J. Anderson (New Spalding Club, 1893), p. 185; A. Macrae, History of the Clan Macrae: With Genealogies (Dingwall, 1899), pp. 142-3; also Selected fusticiary Cases, 1624-1650, S. A. Gillon and J. I. Smith (eds), 3 vols (Stair Soc., 1953-74), vol. III, pp. 564-71. The ecclesiastics who sent their sons to the university at times combined a landholding position, hence the high percentage when the two figures for the landlords and clergy are added together.

46. For example, Archibald Davidson, son of Adam Davidson, burgess of Inverness and indweller in Thurso, went to the University of St Andrews: Fasti, ed. Scott, vol. VII, p. 106; vol. VIII, p. 674; Accounts of the Collectors of Thirds of Benefices, 1561-1572, ed. G. Donaldson (SHS, 1949), p. 208; Early Records of the University of St Andrewes: The Graduation Roll, 1413-1579, and the Matriculation Roll, 1473-1579, ed. J. M. Anderson (SHS, 1926), pp. 297, 300, 304, 307; Royal Commission on the Ancient and Historical Monuments and Constructions of Scotland [RCAHMS], Third Report and Inventory of Monuments and Constructions in the County of Caithness (London, 1911), pp. 113-4. Mr Martin Macpherson, a graduate of Glasgow University, was the son of John Bain Macpherson, "warrior": Fasti, ed. Scott, vol. VII, pp. 194-5; vol. VIII, p. 690; Scottish Genealogy Society, The Scottish Genealogist, vol. I, nos. 2-3 (Apr.-Jul. 1954), p. 27; Munimenta Alme Universitatis Glasguensis: Records of the University of Glasgow from Its Foundation till 1727, ed. C. Innes, 4 vols (Maitland Club, 1854), vol. III, pp. 19, 82. 
corroborates the view that work placement suited the economies of the pre-industrial West. ${ }^{47}$

The Lowland or English perspective of mono-centric civility, as solely radiating from the centre to the periphery, needs to be challenged. Cultural education was available in a Highland milieu among the peers of the realm. This meant that the "civilizing" process was partly an indirect one or even, one might say, a peripheral one. In the closing years of the sixteenth century, possibly in April 1596, Denis Campbell, Dean of Limerick, produced an account of the Western Isles for Queen Elizabeth of England. In it, he described a young Donald Macdonald of Sleat as having been "trained up in learning and civility" at the residence of Archibald, Seventh Earl of Argyll. ${ }^{48}$ Under the influence of the House of Sutherland, the erstwhile rough Donald Mackay presented a different, softened aspect to his English audience at court for his knighthood in 1616 as "comely, firm and very portlike". ${ }^{49}$ Less than two decades later, in 1631, the English comments on his appearance at his trial at Westminster for high treason had hardly evolved. Sir Donald still looked "comely [...] very port-like and of staid countenance". ${ }^{50}$ Notably, the Strathnaver leader adopted an element of Latinate culture and changed the Gaelic slogan of the clan from bi treun, or "be valiant", to its Latin equivalent manu forti, "with a strong hand". ${ }^{51}$ In essence, a component of

47. NAS, CC4/2/1, bundle 1633, legacy of the late William Strachan, 15 Jun. 1633. Albeit of a later date (1658), a good insight into indentured service can be found in NAS, Cromartie Muniments, GD305/1/147/2. On this point, one should consult Becker, Human Capital, p. 20. The search across the printed and manuscript registers of students enrolled at Scottish and English universities is not facilitated by the anonymity of the records which tended to list only the Christian names and surnames of the students. Undoubtedly, these would have incorporated sons of burgesses. However, the gift of chaplainries to fund schooling for children with a view for the recipients subsequently to enter the ministry was granted to a number of burgesses but these were not residents in the northern shires: NAS, CH4/1/1-4; PS1/53-67. Lastly, the fact that burgesses did not tend to use the title "Mr" suggests that they did not graduate but might have nonetheless attended university.

48. Calendar of State Papers Relating to Scotland and Mary, Queen of Scots, 1547-1603 [CSP, Sco.], J. Bain et al. (eds), 13 vols (Edinburgh, 1898-1969), vol. XII, p. 205 n.; Highland Papers, ed. Macphail, vol. II, p. 267.

49. Grimble, Chief of Mackay, pp. 59-65. On some bellicose and lawless traits of character of Donald Mackay, one can consult Grimble, Chief of Mackay, p. 59; A. Mackay, The Book of Mackay (Edinburgh, 1906), p. 126; NAS, Particular Register of Hornings and Inhibitions, Inverness, 1st ser., DI62/4, fos. 134r-5v.

50. Cobbett's Complete Collection of State Trials and Proceedings for High Treason and Other Crimes and Misdemeanors from the Earliest Period to the Present Time, T. B. Howell and T. J. Howell (eds), 34 vols (London, 1809-28), vol. III, col. 486. The trial itself can be consulted in ibid., Howell and Howell (eds), vol. III, cols $483-520$.

51. A. Mackay, "An Account of the Aberach-Mackay Banner, Now Exhibited in the National Museum", PSAS, vol. XXXVIII (1903-4), pp. 527-9; A. Mackay, "The Aberach-Mackay Banner", Celtic Monthly, vol. VI (1898), pp. 171-5; J. Sinclair (ed.), The Statistical Account of Scotland, 1791-1799 [OSA], D. J. Withrington and I. R. Grant (eds), 20 vols (Wakefield, 1973-83), vol. XVIII, p. 477. Much was probably lost in terms of banners and ensigns among the Scottish clans. A mere quote 
social regulation from below complemented the pressure for behavioural reform contained within the top-down social discipline.

Finally, although difficult to decipher, cultural influences must have prevailed upon far northern leaders away from their residences when in the Lowlands, at court, or abroad altogether. ${ }^{52}$ Just as Siberian Cossacks used literacy to exploit administrative and commercial opportunities and so pragmatically upheld their interests, Sir Robert Gordon, Tutor of Sutherland, likewise put to good use his interest in civil law while in France with access to leading institutions in that field at Poitiers, Orleans, and Bourges. Apologists of the emergent neo-Stoic thought endorsed the Tacitean aspiration for a reconfiguration of political morality along pragmatic lines, however disturbing these were. The defence of kinship thus became paramount over the immorality of the actual act(s) and justified it/them This philosophy peppered Sir Robert's genealogical work in the defence of the House of Sutherland and was carried out in actions and legal deeds in the defence of the comital House sometimes at the expense of morality. ${ }^{53}$

At a more practical level, contemporary fashion imposed itself on the clan elite who acquired stylish pieces of furniture and other goods, like the refined carved oak sideboard thought to have been imported from London alongside a silver communion cup by Sir Rory Macleod of Dunvegan during his stay at court in 1613. Yet, Sir Rory carved his coat-of-arms on the cup which featured two symbolic charges characteristic of Highland heraldry, namely the lion rampant, also a royal charge, and the galley. ${ }^{54}$ Clan chiefs projected a pictorial personal pride of their

from a mid- to late-16th century piece of bardic praise-poetry of the Campbells revealed Clan Ranald as ealta sluaigh na meirgeach maoth, "those fighting bands of the ensigns of silk", and the Macleods as Fine Leóid na mbratach mbodhbha, "Tribe of Leod of the belligerent banners": Duanaire na Sracaire Songbook of the Pillagers: Anthology of Scotland's Gaelic Verse to 1600, W. McLeod and M. Bateman (eds) (Edinburgh, 2007), pp. 146-7, also 412-3; J. Macdonald, "An Elegy for Ruaidhrí Mór", SGS, vol. VIII (1958), pp. 40-1; A. Matheson, "Poems from a Manuscript of Cathal Mac Muireadhaigh", Éigse, vol. XI (1964-66), p. 1; Gàir nan Clàrsach: The Harps' Cry, C. Ó Baoill and M. Bateman (eds) (Edinburgh, 1994), pp. 86-7.

52. That is beside the other means responsible for the penetration of cultural influences in any given area either through books or trade for instance.

53. C. Witzenrath, "Literacy and Orality in the Eurasian Frontier: Imperial Culture and Space in Seventeenth-Century Siberia and Russia", Slavonic and East European Review [SEER], vol. LXXXVII (2009), pp. 63-77; D. Allan, "'Ane Ornament to Yow and Your Famelie': Sir Robert Gordon of Gordonstoun and the Genealogical History of the Earldom of Sutherland", Scottish Historical Review [SHR], vol. LXXX (2001), pp. 24-44, especially 40-44; Allan, "Pedigree and Propaganda", pp. 151, 159; NLS, Dep. 175/65, nos. 58, 84, 103. Beside networking, corruption lubricated legal businesses for prosperous far northerners.

54. F. T. MacLeod, "Notes on the Relics Preserved in Dunvegan Castle, Skye, and the Heraldry of the Family of Macleod of Macleod", PSAS, vol. XLVII (1912-13), pp. 118-9, 123-4 dated the sideboard to 1603 and of an Edinburgh origin; Book of Dunvegan, ed. MacLeod, vol. I, p. XLVI; 
own sense of accomplishments in exile. Sir Donald Mackay, Lord Reay, reflected his martial feats in the Thirty Years' War by bearing a pikeman and a musketeer as dexter and sinister heraldic supporters respectively. ${ }^{55}$

Despite the partly intangible character of educational and cultural influences on exiled far northerners, it seems that they had an impact on at least a number of them once they returned to their home environment. This was an ongoing process of integration into wider Scottish and British society and of greater biculturalism with numerous variables that affected individuals and communities alike. At least the clan elite tended to retain elements of Gaelic culture, including those on the far northern-eastern seaboard, and associated these with non-native ones. The phenomenon amplified the pre-existing dual and hybrid culture and integration. However, the process needs to be studied over the longue durée. It was by no means a phenomenon that universally affected the far north but rather one that gradually unfolded with geographical and societal variations.

\section{Conclusion}

Just as Muscovy employed Tatars in its army and did not bestow high official positions on them while its Siberian Cossacks maximized their access to literacy, the Scottish far northerners, in similar circumstances abroad and back at home, exploited their situation through the use of

Grant, MacLeods, pp. 219, 243; A. Campbell, "A Closer Look at West Highland Heraldry", Double Tressure, vol. XIX (1997), pp. 46-7, 49-50, 59. The official guide to the castle comments that the sideboard bears the date 1603 and was brought by Sir Rory after his sojourn in London in 1613: John MacLeod, Official Guide, Dunvegan Castle, Isle of Skye, Scotland (2003, Dunvegan Castle, current [2009?] ed.), p. 19.

55. NAS, GD84/2/246, frontispiece; Lyon Office, Edinburgh, Kings and Nobilities Arms II, MS21, pl. 109. Sir James Balfour's and Pont's Manuscripts recorded the alternative heraldic charge of two hands holding two drawn swords rather than daggers: NLS, Scottish Heraldry, Blazons of Scottish Arms by Sir James Balfour of Denmilne, 1630, Adv. MS 15.1.11, fo. 34v; Lyon Office, Pont's Manuscript, MS1, p. 36 n. 46. On his 1623 targe, the hand does not grasp the sword: The Hunterian Museum, University of Glasgow, GLAHM C.72, available online at <http://www. huntsearch.gla.ac.uk/cgi-bin/foxweb/huntsearch/DetailedResults.fwx?collection=all\&SearchTer m=C.72\&mdaCode=GLAHM\&reqMethod=Link $>$, accessed 30 April 2010. Aonghas MacCoinnich deserves our gratitude for this reference. It is significant that prior to Reay's time, the Mackay hand was displayed appaumé rather than associated with these bladed weapons (Mackay, "Account of the Aberach-Mackay Banner", pp. 527-32). Colonel George Matheson had his heraldic arms registered with the Lord Lyon on 5 October 1639 with an armed hand holding a naked sword for his crest, underlining his military exploits. Matheson traditions and genealogies have that he was George of Shinness in Sutherland: NLS, Adv. MS 15.1.11, fo. 35r; A. Mackenzie and A. MacBain, History of the Mathesons with Genealogies of the Various Families (2nd ed., Stirling, 1900), pp. 140-1; EUL, Sir Roderick Murchison Collection, MS 2262/2/2/2. 
networks to augment their benefits. Ironically, and perhaps most importantly, the traditional historiography of State relationships with the clans and vice versa as defined by a language of antagonism is reductionist in its approach. Indeed, the terminology of cooperation and symbiosis, as ends rather than means, and even if imposed and fortuitous, should transcend the debate and not be underplayed. ${ }^{56}$ As such, the Crown promoted the diffusion of Renaissance ideals which partially reformed the character and behaviour of a number of the clan elite and others. The military co-optation allowed this middling sort (at the State level) both in exile and on their return to Britain to position itself for the promotion of their own interests and that of the clan. The State reformed the northern communities but not single-handedly. Social transformations came from below too perhaps most visibly and profoundly at the cultural level. To some extent, what the Crown tried with difficulties to impose in the socalled "civilizing" of the far north was somewhat accomplished almost imperceptibly by cultural influences. One of the agents for this evolution lay in the exile and return of far northerners which brought not only new material culture but also innovative visions and ideas into the region. Because of the vast power exercised by the clan elite within their sphere of influence, be it socio-economic, administrative, judicial, and cultural, the impact of these changes on the ground was significant in a pattern of hybridizing or bicultural integration. The result is a picture less of a retrograde, stultified, and monolithic society, though with some elements of this remaining, but more of a slowly moving and diverse one engaged in and selectively responding to a pre-existing but amplified early-modern bicultural process.

In that sense, the clan military force and network survived by its transposition into an official body, equally military in its nature. This institutionalization of the private sphere into the public sphere resulted in an actual geographical displacement in terms of the military with soldiers in foreign service. The experiences brought back by returning soldiers remoulded both individuals and communities in a process of social regulation which was most visible at the material level but with an inkling of substantial psychological impacts too.

A corresponding phenomenon is discernible in the exile and return of members of the clan elite and others to Europe for educational and cultural purposes which (re)shaped, mutatis mutandis and in a more pronounced way, their native culture into a pre-existent hybrid society in their integration into a Lowland and British genteel model. The response

56. Witzenrath, Cossacks, especially ch. 3; Witzenrath, "Literacy"; H. H. Nolte, "Internal Peripheries: From Andalucia to Tatarstan", Review, vol. XVIII (1995), pp. 269-70. 
of the northern Highlanders, as homo peregrinator, to the push and pull factors of exile and return was to adapt and utilize the opportunities forced onto or presented to them by the State or which arose from Rinascimento culture. They used their various kinship ties and other networks to the full for a constant re-alignment according to their respective interests. The concomitant participation of far northerners in patterns of military and educational exile projected the image of the Highlanders and their society abroad, even if indirectly. In Scotland itself, it helped redefine and re-assess the perception of an immovable and immutable society solely immersed in clan warfare. The phenomenon further testified to the partial integration of the clan elite into the wider Scottish and British society which was gradually taking place and which percolated through to the lower orders of these boreal communities. In fine, this remained an ongoing process best studied over the longue durée and with significant variations both in terms of geography and, within communities, within clans and families themselves.

\section{Bibliography}

\section{Primary sources}

\section{Manuscript sources:}

Aberdeen University Library, Special Collections, Aberdeen: volume shelf-marked "BK Rud [1-6]".

Edinburgh University Library, Edinburgh:

Sir Roderick Murchison Collection, MS 2262.

Lyon Office, Edinburgh:

Kings and Nobilities Arms II, MS21.

National Archives of Scotland, Edinburgh:

Commissariot of Edinburgh, Register of Testaments, CC8;

Glasgow Commissary Court Records, CC9;

Church of Scotland Records, Register of Presentations to Benefices, CH4;

Particular Register of Hornings and Inhibitions, Inverness, 1st ser., DI62;

Exchequer Records, Taxation Papers, E68;

Reay Papers, GD84;

Justiciary Records, Books of Adjournal, JC2;

Calendar of Documents Presented to H. M. General Register House, Edinburgh, by the Rt. Hon. the Baron Reay, ed. C. T. Innes (1929). 
National Library of Scotland, Edinburgh:

Gordons of Gordonstoun and Cummings of Altyre Papers, Dep. 175, Acc. 10824;

Sutherland Papers, Dep. 313.

Scottish Catholic Archives, Edinburgh:

Colleges Abroad, CA4.

Printed sources:

The Book of Dunvegan, ed. R. C. MacLeod, vol. I, Third Spalding Club, 1938.

Calendar of State Papers, Domestic Series, of the Reign of Charles I, 1625-49, J. Bruce et al. (eds), 23 vols, London, 1858-97.

Collectanea de Rebus Albanicis: Consisting of Original Papers and Documents Relating to the History of the Highlands and Islands of Scotland, W. F. Skene (ed.), Iona Club, 1847.

Duanaire na Sracaire Songbook of the Pillagers: Anthology of Scotland's Gaelic Verse to 1600, W. McLeod and M. Bateman (eds), Edinburgh, 2007.

The Earl of Stirling's Register of Royal Letters, Relative to the Affairs of Scotland and Nova Scotia from 1615 to 1635, C. Rogers (ed.), 2 vols, Edinburgh, 1885.

Gàir nan Clàrsach: The Harps' Cry, C. Ó Baoill and M. Bateman (eds), Edinburgh, 1994.

Gordon R., A Genealogical History of the Earldom of Sutherland, Edinburgh, 1813.

Highland Papers, J. R. N. Macphail (ed.), 4 vols, Scottish Historical Society, 1914-34.

Matheson A., "Poems from a Manuscript of Cathal Mac Muireadhaigh", Éigse, vol. XI (1964-66), pp. 1-17.

Monro R., Monro His Expedition with the Worthy Scots Regiment (Called MacKeyes Regiment), London, 1637.

The Munro Tree: A Genealogy and Chronology of the Munros of Foulis and Other Families of the Clan, A Manuscript Compiled in 1734, R. W. Munro (ed.), Edinburgh, 1978.

Old Ross-shire and Scotland As Seen in the Tain and Balnagown Documents, W. Macgill (ed.), 2 vols, Inverness, 1909-11.

Origines Parochiales Scotiae: The Antiquities Ecclesiastical and Territorial of the Parishes of Scotland, C. Innes and J. B. Brichan (eds), 2 vols, Bannatyne Club, 1851-55.

The Register of the Privy Council of Scotland, J. H. Burton et al. (eds), 38 vols, Edinburgh, 1877-1970.

Social Life in Former Days: Second Series, Illustrated by Letters and Family Papers,

E. D. Dunbar (ed.), Edinburgh, 1866.

The Sutherland Book, W. Fraser (ed.), 3 vols, Edinburgh, 1892. 


\section{Secondary sources}

Astoul G., Les Chemins du Savoir en Quercy et Rouergue à l'Époque Moderne : Alphabétisation et Apprentissages Culturels, Toulouse, 1999.

Bracewell C. W., The Uskoks of Senj: Piracy, Banditry, and Holy War in the Sixteenth-Century Adriatic, Ithaca, 1992.

Broun D. and MacGregor M. (eds), Miorun Mòr nan Gall, "The Great Ill-Will of the Lowlander"?: Lowland Perceptions of the Highlands, Medieval and Modern, Glasgow, 2009.

Brown K. M., Noble Society in Scotland: Wealth, Family and Culture, from Reformation to Revolution, Edinburgh, 2004.

Burke P., Popular Culture in Early Modern Europe, 1978, 3rd ed., Farnham, 2009.

Campbell A., "A Closer Look at West Highland Heraldry", Double Tressure, vol. XIX (1997), pp. 46-67.

Cathcart A., Kinship and Clientage: Highland Clanship, 1451-1609, Leiden, 2006.

Duffy P. J. et al. (eds), Gaelic Ireland, c. 1250-c. 1650: Land, Lordship and Settlement, Dublin, 2001.

Gaertner J. F. (ed.), Writing Exile: The Discourse of Displacement in GrecoRoman Antiquity and Beyond, Leiden, 2007.

Glozier M., Scottish Soldiers in France in the Reign of the Sun King: Nursery for Men of Honour, Leiden, 2004.

Goodare J., State and Society in Early Modern Scotland, Oxford, 1999.

Grosjean A., An Unofficial Alliance: Scotland and Sweden, 1569-1654, Leiden, 2003.

Houston R. A., Literacy in Early Modern Europe: Culture and Education, 1500-1800, 2nd ed., Harlow, 2002.

Kirby D., Northern Europe in the Early Modern Period: The Baltic World, 1492-1772, London, 1992.

Macinnes A. I., The British Revolution, 1629-1660, Basingstoke, 2005.

Maclean L. (ed.), The Middle Ages in the Highlands, Inverness, 1981.

—, The Seventeenth Century in the Highlands, Inverness, 1986.

Meikle M. M., A British Frontier?: Lairds and Gentlemen in the Eastern Borders, 1540-1603, East Linton, 2004.

Murdoch S., Network North: Scottish Kin, Commercial and Covert Associations in Northern Europe, 1603-1746, Leiden, 2006.

- (ed.), Scotland and the Thirty Years' War, 1618-1648, Leiden, 2001.

Murdoch S. and Mackillop A. (eds), Fighting for Identity: Scottish Military Experience, c. 1550-1900, Leiden, 2002.

Parkes P., "Celtic Fosterage: Adoptive Kinship and Clientage in Northwest Europe", Comparative Studies in Society and History, vol. XLVIII (2006), pp. 359-95. 
Rackwitz M., Travels to Terra Incognita: The Scottish Highlands and Hebrides in Early Modern Travellers' Accounts, c. 1600 to 1800, Münster, 2007.

Selwyn J. D., A Paradise Inhabited by Devils: The Jesuits' Civilizing Mission in Early Modern Naples, Aldershot, 2004.

Shuger D., "Irishmen, Aristocrats, and Other White Barbarians", Renaissance Quarterly, 1 (1997), pp. 494-525.

Tо́тн I. G., Literacy and Written Culture in Early Modern Central Europe, Budapest, 2000.

Watt D. E. R., "Education in the Highlands in the Middle Ages", in L. Maclean, Middle Ages, pp. 79-90.

Withrington D., "Education in the 17th Century Highlands", in L. Maclean, Seventeenth Century, pp. 60-9.

Witzenrath C., Cossacks and the Russian Empire, 1598-1725: Manipulation, Rebellion and Expansion into Siberia, London, 2007.

Worthington D., Scots in Habsburg Service, 1618-1648, Leiden, 2004.

\section{Newspapers, Magazines}

Clan Munro Association, Clan Munro Magazine, [Perth], 1939-.

Scottish Genealogy Society, The Scottish Genealogist, [Edinburgh], 1954-.

\section{Internet resources}

The Hunterian Museum, University of Glasgow, GLAHM C.72, available online at <http://www.huntsearch.gla.ac.uk/cgi-bin/foxweb/ huntsearch/DetailedResults.fwx? collection=all\&SearchTerm $=$ C. 72 $\&$ mdaCode=GLAHM\&reqMethod $=$ Link $>$, accessed 30 April 2010 .

"Scotland, Scandinavia and Northern Europe, 1580-1707", S. Murdoch and A. Grosjean (eds), available online at <http://www.st-andrews. ac.uk/history/ssne/index.php>, accessed 19-20 February 2005. 